UDC 911.3:314.7

Victor Anatoliyovych Parenyuk,

$\mathrm{PhD}$ student, Department of Economic and Social Geography,

Taras Shevchenko National University of Kyiv, 64/13 Volodymyrska St., Kyiv, 01601, Ukraine, e-mail: parenvic@,i.ua, https://orcid.org/0000-0001-7098-6977;

Nataliia Ivanivna Provotar,

PhD (Geography), Associate Professor of Department of Economic and Social Geography,

Taras Shevchenko National University of Kyiv,

e-mail: provotarnat@ukr.net, https://orcid.org/0000-0003-2211-6509;

Kostyantyn Volodymyrovych Mezentsev,

DSc (Geography), Head of Department of Economic and Social Geography,

Taras Shevchenko National University of Kyiv,

e-mail: mezentsev@,knu.ua, https://orcid.org/0000-0003-1974-7860

\title{
YOUTH MIGRATION IN UKRAINE: REGIONAL DIMENSION
}

В. А. Паренюк, Н. І. Провотар, К. В. Мезенцев. МІГРАЦЇ̈ МОЛОДІ В УКРАЇНІ: РЕГІОНАЛЬНИЙ ВИМІР. Метою даного дослідження є аналіз регіональної диференціації міграчійних потоків молоді та проведення типізації регіонів України за особливостями міграційної поведінки молоді. У роботі використано кореляційний аналіз, кластерний аналіз та побудовано карти самоорганізаџіï Кохонена. Аналіз просторових відмін міграчії молоді у міській та сільській місцевості свідчить про різноспрямованість міграчійних потоків. Виявлено, що міграчії молоді пов 'язані з рівнем безробіття та інвестииіийною привабливістю регіонів. Підтверджено припущення, щзо на міграції молоді із сільської місиевості впливають не тільки економічні чинники, але й відсутність перспектив отримання вищої освіти, робочих місиь та «культура міграцій». Аналіз зв'язку між доходами населення та масштабами виїзу молоді свідчить, що наявні окремі ознаки оберненої $U$ подібної залежності. В иілому результати дослідження підтвердили, що на регіональному рівні економічні фактори (безробіття, інвестиції, а також доходи) впливають на міграції молоді в Україні, проте їх вплив необхідно розглядати в більш широкому контексті місиевої специфіки людського капіталу та зміни життсвого етапу молоді. За результатами кластерного аналізу та побудови карт самоорганізації Кохонена виділено п'ять кластерів регіонів за подібністю показників міграиій молоді. Аналіз міграиій молоді у 2002-2019 роках дозволив ідентифікувати шість моделей динаміки (монотонного скорочення, стрибкоподібної динаміки з тенденцією до скорочення, стрибкоподібної динаміки без змін, стрибкоподібноі динаміки з тенденцією до зростання, монотонного зростання, відсутності змін). Виділені кластери регіонів та моделі динаміки стали основою для ідентифікачії типів регіонів, які можуть бути орієнтирами при формуванні регіональної міграчійної політики в Україні.

Ключові слова: молодь, мігращиї, регіон, фактори міграчій, типізачія, Украӥна.

В. А. Паренюк, Н. И. Провотар, К. В. Мезенцев. МИГРАЦИИ МОЛОДЕЖИ В УКРАИНЕ: РЕГИОНАЛЬНОЕ ИЗМЕРЕНИЕ. Целью данного исследования является анализ региональной дифференциации миграционных потоков молодежи и типизачия регионов Украины по особенностям миграчионного поведения молодежи. В работе использованы корреляиионный анализ, кластерный анализ и построены карты самоорганизации Кохонена. Анализ пространственных различий миграиии молодежи в городской и сельской местности свидетельствует о разнонаправленности миграчионных потоков. Выявлено, что миграции молодежи связаны с уровнем безработицы и инвестиционной привлекательностью регионов. Подтверждено предположение, что на миграции молодежи из сельской местности влияют не только экономические факторы, но и отсутствие перспектив получения третичного образования, рабочих мест и «культура миграций». Анализ связи между доходами населения и масштабам выезда молодежи свидетельствует, что есть отдельные признаки перевернутой Uобразной зависимости. В иелом результаты исследования подтвердили, что на региональном уровне экономические факторы (безработииа, инвестиции, а также доходы) влияют на миграции молодежи в Украине, однако их влияние необходимо рассматривать в более широком контексте местной специфики человеческого капитала и изменения жизненного этапа молодежи. На основе результатов кластерного анализа и построения карт самоорганизации Кохонена выделено пять кластеров регионов по сходству показателей миграции молодежи. Анализ миграций молодежи в 2002-2019 годах позволил идентифицировать шесть моделей динамики (монотонного сокращения, скачкообразной динамики с тенденцией к сокращению, скачкообразной динамика без изменений, скачкообразной динамики с тендениией к росту, монотонного роста, отсутствия изменений). Выделенные кластеры регионов и модели диналики стали основой для идентификации типов регионов, которые могут быть ориентирами при формировании региональной миграционной политики в Украине.

Ключевые слова: молодежь, миграции, регион, факторы миграций, типизация, Украина.

Research problem introduction. Modern migration is characterized by multidirectional nature and waviness as a response to various political and socio-economic challenges. Simultaneously, its distinct features are a steady increase in volumes and changing structure, as well as diversity, complicated interrelation, and ambiguity of underlying factors. To some extent, the important part of migration flows is young people, both in terms of the sheer numbers involved and because they often act as trendsetters in mobility flows [1]. The migration intentions of youth can determine the future development of countries, regions, and individual communities. Young people are more likely to migrate since they have relatively more time for career growth and can therefore benefit more from moving to a new place. Besides, young people have invested significantly less (particularly in the form of taxes) in their country of origin than the older population, which influences their migration decisions [2]. 
However, attachment to the place of residence or limited financial means may, on the contrary, prevent them from migrating $[3,4,5]$.

The migration activity of young people worldwide tends to increase from $2.9 \%$ in 1990 to $3.6 \%$ in 2019 [6]. In 2019, the youth net migration in Ukraine was positive and amounted to 1.6 people per thousand inhabitants, but with significant differences across regions. Thus, in Kyiv, the net migration was 19.2 per 1,000 inhabitants, while in Kirovohrad region, it was $-6.3 \%$. This actualise the study of regional differentiation of youth migration in Ukraine in terms of factors, composition, and directions of migration flows. Moreover, Ukraine is mainly a supplier of educational migrants to other countries due to increased access to education abroad (mainly in EU countries bordering Ukraine), expanded international cooperation with Ukrainian universities, and deepened economic relations with the EU [7].

Youth are most inclined to make radical migration decisions, and at the same time, it is of the highest importance for accelerating the economic development of any country [8]. Young people see migration as a source of new social experience in education, work, and culture. Additionally, it is an opportunity to become an integral part of the economic and socio-cultural environment of the recipient country, invest their human capital successfully, and become a part of a society that is attractive in terms of values and civil rights [9]. Dominated by educated youth, modern migration is a distinct manifestation of globalization problems and differentiation of countries by socio-economic and political criteria [10].

In recent years, there has been a diversification of youth migration, the transformation of patterns, and blurring of the borders between different types of mobility, including in Ukraine [11]. Youth migration has considerable demographic and socioeconomic consequences [12, 13, 14, 15]. Even the growth of investment attractiveness and financial capacity of the population does not guarantee a weakening of the migration outflow of young people from Ukraine and especially from some regions [16]. The solution to this problem may lie in the implementation of effective regional strategies by local authorities to address youth unemployment, on the one hand, and reducing the migration outflow, and taking into account the liquid nature of modern youth migration, on the other.

Identification of the research gap. A considerable number of studies on various issues of youth migration cover the economic, social, and psychological aspects of the problem. However, the spatial one remains insufficiently discussed, particularly studying youth migration in terms of regional differ- entiation of migration flows, determining their factors, trends, and regional problems connected with youth migration.

The purpose. Given the above, this study aims to analyze the regional differentiation of young people's migration flows and to typify the regions of Ukraine according to the characteristics of the migratory behavior of the youth. Accordingly, the research questions are as follows. First, what is the relationship between economic indicators (income, unemployment, investment) and youth migration at the regional level? Second, how do the regions of Ukraine differ in the scale, structure, and dynamics of youth migration flows? Third, what types of regions can be identified, and can they be considered the ones to determine the young people's intention to migrate?

Literature review. Migration is most often motivated by the search for a better life [17]. However, economic factors such as the income can be both a stimulus and a deterrent. Young people are leaving regions and countries to improve living conditions, but lack of financial means may prevent them from migrating, especially to other countries. Although an increase in wealth may augment the migration possibilities, it may simultaneously decrease the migration propensity by raising opportunity costs [5].

The results of empirical studies are ambiguous, with some concluding that people with higher incomes are more likely to migrate [3], while others have found that young people from areas with high income per capita are less likely to migrate [18]. At the macro level, the relation between well-being and migration is characterized by an inverse U-shape. The same dependence can be assumed at the regional level. Thus, the relation between wealth and migration may differ across regions, take different forms in different areas [5].

A number of studies show that the critical factors of youth migration are the situation in the labor market and education, lack of employment, and educational opportunities [3, 19, 20]. Education levels could shape mobility patterns, while youth undertake migration to foster educational attainment [21], more skilled and educated youth are more prone to migration $[3,19,20]$, and tertiary level graduates are generally more mobile than the rest of the population [22]. The availability and diversity of tertiary education facilities influenced the out-migration intention [4].

Along with economic factors, local amenities (e.g. public services, security, transport infrastructure, housing, etc.) play an important role in migration decisions [5]. In particular, in the post-Soviet space the marginalization of some rural areas accompanied by rural population decrease and closing 
down of many vital social structures (schools, pharmacies, libraries, local pubs) can cause youth escape and thus be perceived as a "loss of a new generation" [23]. As a result, a pronounced migration pattern is formed when youth migrate from rural to urban areas, and from less-developed to moredeveloped regions [21, 24]. Metropolitan centers in the more developed regions have become the main destination for youth migration internally and more developed countries internationally, particularly for economic and educational reasons [4, 20]. Consequently, it would impact on 'youth urbanization' as well as disparity of human capital development between the least and the most developed regions in the country [20].

Therefore, it is suggested that improving local conditions may reduce the impact of the push factor and reduce the outflow of young people. Instead, some studies do not support this assumption. For instance, Drozdzewski [4] concludes that an increase in educational facilities would not necessarily increase retention rates. Roth and Hartnett [25] do not find that benefitting from the youth outreach centers in the Central American region significantly impacts youths' intentions to migrate. Thus, the link between youth migration and local conditions needs to be seen in a broader context, considering income levels and employment in the regions. Moreover, the latest research shows that youth migration cannot be explained solely by push-pull factors. Even potentially effective measures aimed at deterring young people from migrating can have minimal impact.

Large numbers of out-migration may generate a "culture of migration" and as a result, migration becomes a normal thing to do, whereas staying at home is perceived as a failure [26]. The outmigration of an older sibling and own previous travel experiences also may increase the propensity for young people to intend to leave [4].

Engbersen [27] talks about the new, liquid nature of migration, when migrants choose individualized migration paths and look for new places to work and live, using open borders and labor markets, and focusing entirely on their own careers. Liquid migration is usually individualized, temporary, multidirectional, legal and unpredictable [27]. The prominent manifestation of liquid migration is student migration.

Thus, migration of young people in a generalized view can be considered as a consequence of economic push factors (income, employment). Scrutinizing migration allows us to see the impact of underinvestment in the regions, and as a consequence, the lack or inadequate quality of local amenities. Moreover, modern trends of individualized youth decisions and liquid migration, which is also characterized by a 'double transition' in post-socialist space, when the post-socialist transition took place in parallel with the transition from youth to adulthood are superimposed on this [28, 29]. Such migration trends can be manifested in many ways in different regions.

Among the main reasons for labor and educational migration of young people from Ukraine are most often called inefficient youth policy, relatively high unemployment among young people, the inability to work in their professional field, the desire to obtain a European diploma, and unstable socioeconomic and political situations $[30,31]$. The insufficient supply of professional job opportunities in Ukraine can be partly explained by the large number of higher education institutions, low level of awareness about the actual state and dynamics of the labor market and demand for specific professions, as well as the choice of 'prestigious' specialties without real employment opportunities after graduation. That is why young people make up a third of the unemployed in Ukraine [32].

Youth migration is primarily caused by uneven regional development in terms of welfare, income, social stability, availability of various amenities, quality of education, provision of information and communication technologies, etc. [9]. In recent decades, there has been a significant regional differentiation of economic factors of unemployment and youth migration due to the concentration of the highest incomes, investments, and business activity in several regions with a high level of socioeconomic development. The widening of the financial gap between regions and the strengthening of negative socio-economic processes in regions that receive little investment in fixed assets for the development of innovative sectors of the economy, job creation will keep encouraging young people to seek better living and employment conditions beyond such regions, in metropolises or abroad [16].

Data and methods. This study is based on the data from the State Statistics Service of Ukraine. In particular, we used the indicators of youth migration in general, youth migration in urban settlements and rural areas, male and female, external youth migration, as well as economic indicators (average monthly wages, disposable income and expenditure per capita, the employment rate of the entire population and youth employment rate, unemployment rate of the entire population and young people and fixed capital investment per capita) showing individual regions of Ukraine.

Pearson's correlation coefficients were calculated to assess the relationship between youth migration and economic indicators (average monthly wages, disposable income and expenditures per capita, employment and unemployment rates of the total population and young people, and fixed capital 
investment per capita). To prevent skewed indicators distribution, the city of Kyiv was excluded from the analysis (because it differs significantly from other regions by selected indicators). We conducted the cluster analysis (using Statistica analytics software package, Ward's method) and constructed Kohonen self-organizing maps (using Deductor Studio analytics software package) to study the regional differentiation of youth migration according to the techniques described in [33]. Based on the analysis of spatial and temporal (2002-2019) trends of youth migration, we developed an empirical typification of Ukrainian regions in terms of youth migration behavior.

\section{Main findings: results and discussion.}

The spatial differences in the youth migration were analyzed in two sections: in urban settlements and rural areas. A significant share of youth migration flow is interregional and is directed from rural to urban areas. Thus, the balance of youth migration in urban settlements is positive, and it amounted to 4.8 people per thousand inhabitants in 2019. Rural areas are unattractive for young people in Ukraine. They are characterized by a negative migration balance, except for Kyiv region with large-scale housing construction in the suburbs, being mainly focused on meeting the housing needs of young people. The most intensive migration of young people from rural areas is typical for Kirovohrad region (the net migration of young people from rural areas in 2019 was $-14.6 \%$ ), Sumy (-11.5\%o), Mykolaiiv ($11.1 \%$ ) and Chernihiv (-10.0\%o) regions.

The highest positive values (more than seven people per thousand inhabitants) of youth migration balance are typical for those regions whose centers are million-plus cities such as city of Kyiv, Kyiv, Kharkiv, and Odesa regions. In 2019, 17 Ukraine's regions are chracterised by a negative balance of youth migration.

The interstate youth net migration in Ukraine is positive. In 2019, it amounted to 1.5 people per thousand inhabitants, primarily due to several regions like Kyiv city, Odesa and Kharkiv regions which are the most attractive for migrants. The border regions like Volyn, Rivne, Luhansk, and Kherson have negative values.

We calculated the correlation coefficients to determine how deeply economic factors influence the migration of the population aged 15-34. The chosen economic indicators were the average monthly salary, disposable income and expenditure per capita, employment rate, youth employment rate, unemployment rate, youth unemployment rate, and fixed capital investment per capita. The impact on youth migration was assessed by the indicators of net migration as a whole, separately in urban and rural areas, nale and female, as well as external migration of young people.

According to the results of the analysis (Table 1), the following conclusions can be drawn. Youth migration is most closely linked to the unemployment rates of the population and young people in particular, as well as to the investment attractiveness of the regions, which indirectly demonstrates the prospects for their development. The relationship between youth migration and unemployment is moderately inverse $(r=-0.66$ and $r=-0.59$ for the whole population and youth unemployment, respectively). It is moderately direct ( $r=0.63)$ between migration and fixed capital investment per capita.

Table 1

The correlation coefficients between economic indicators and youth migration

\begin{tabular}{|l|c|c|c|c|c|c|}
\hline & $\begin{array}{c}\text { Average } \\
\text { monthly salary }\end{array}$ & $\begin{array}{c}\text { Income } \\
\text { per capita }\end{array}$ & $\begin{array}{c}\text { Expenditures } \\
\text { per capita }\end{array}$ & $\begin{array}{c}\text { Fixed capital } \\
\text { investment per } \\
\text { capita }\end{array}$ & $\begin{array}{c}\text { Unemploy- } \\
\text { ment rate }\end{array}$ & $\begin{array}{c}\text { Youth unem- } \\
\text { ployment rate }\end{array}$ \\
\hline $\begin{array}{l}\text { Youth net } \\
\text { migration, } \\
\text { total }\end{array}$ & $0,40^{*}$ & 0,42 & 0,61 & 0,63 & $-0,66$ & $-0,59$ \\
\hline urban & 0,21 & 0,42 & 0,63 & 0,53 & $-0,72$ & $-0,66$ \\
\hline rural & 0,35 & 0,18 & 0,38 & 0,52 & $-0,42$ & $-0,3$ \\
\hline male & 0,38 & 0,45 & 0,65 & 0,56 & $-0,67$ & $-0,66$ \\
\hline female & 0,4 & 0,39 & 0,57 & 0,65 & $-0,64$ & $-0,52$ \\
\hline external & 0,22 & 0,46 & 0,54 & 0,28 & $-0,54$ & $-0,6$ \\
\hline
\end{tabular}

Source: State Statistics Service of Ukraine: http://www.ukrstat.gov.ua

* Marked correlations are significant at $\mathrm{p}<0,05$ 
Youth migration in urban areas of Ukraine is also most closely linked to unemployment. The connection is less vivid in rural areas. This confirms the assumption that migration of young people from rural areas is influenced not only by economic factors, but also by the lack of prospects for tertiary education, jobs, and 'migration culture', when the decision to stay is seen as a failure [26]. The connection between migration and the investment attractiveness of the region does not depend on the type of area.

The link between migration and unemployment is closer for young men and weaker for young women, while the connection with investment attractiveness is more vivid for young women. To some extent, this can be explained by the daily practices typical of the latter. The highest volumes of net out-migration of young men are typical for Ukraine's regions with the high level of unemployment and harsh competition for vacancies.
External migration of young people is most closely linked to the corresponding unemployment rate. The weak link to the investment volume can be explained by the fact that the decision on external migration is made without considering the investment potential and investment activities in the regions.

The links between youth migration and the average monthly salary and income per capita are weak. Their levels in Ukraine's regions are low compared to the countries attractive for migration or some metropolises of Ukraine, primarily Kyiv.

The analysis of the relation between income and the out-migration scale (Fig. 1) shows some signs of an inverse U-shape curve [5]. Thus, in the regions with the lowest income level, the scale of youth migration is relatively low, and some regions with average income are characterized by the largest outflow of youth. However, the city of Kyiv, with the highest level of income, has an average level of

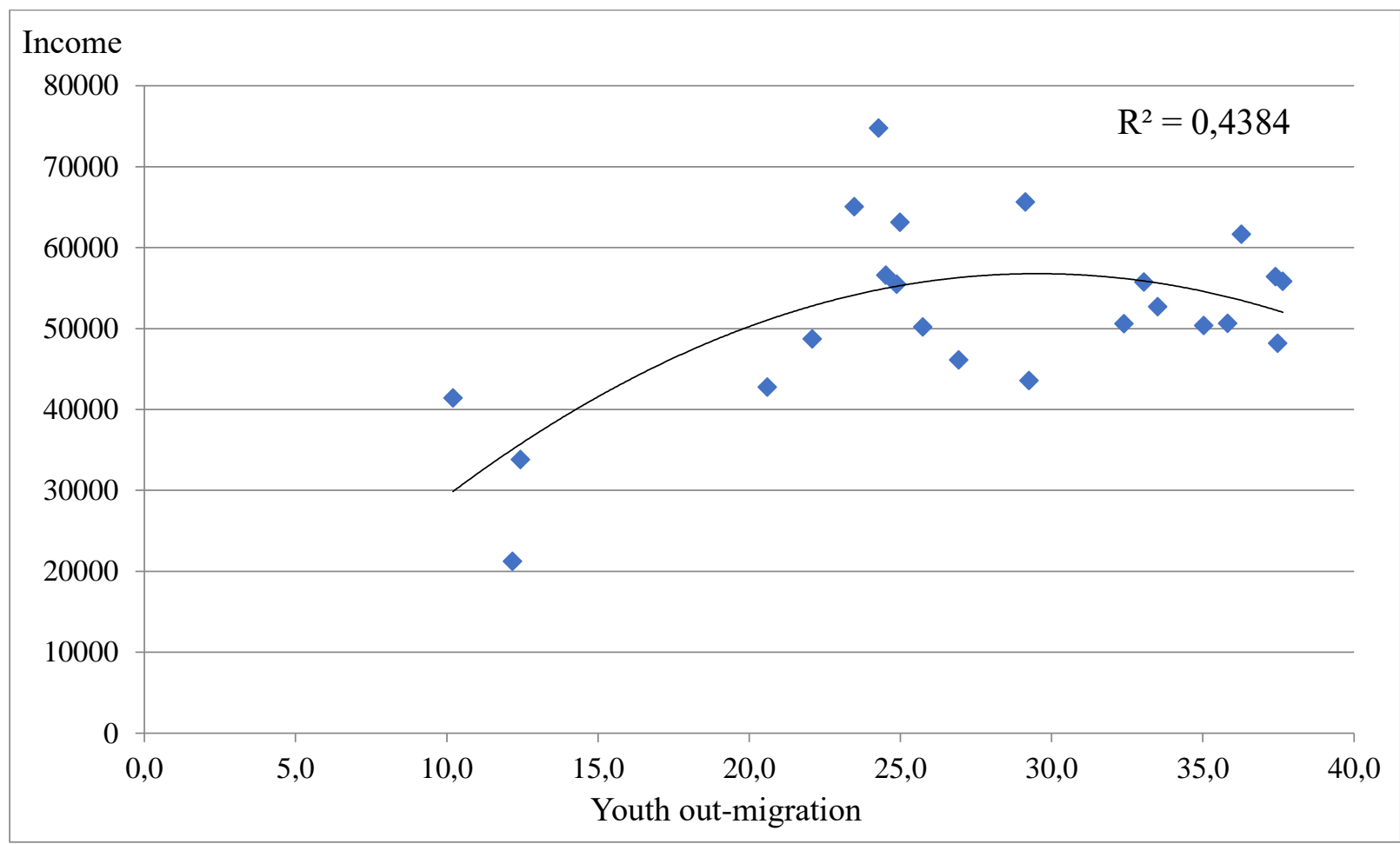

Fig. 1. Relation between youth out-migration (per 1,000 young people) and incomes (per capita) (excluding city of Kyiv). Source: State Statistics Service of Ukraine. http://www.ukrstat.gov.ua

migration outflow.

The grouping of regions according to the indicators of youth migration was carried out using cluster analysis (Fig. 2) and construction of Kohonen self-organizing maps (Fig. 3, Table 2).

The analysis of the tree diagram of clustering according to the indicators of youth net migration in general, in urban and rural areas, by sex and external migration of youth gives grounds to identify five clusters of regions of Ukraine. The composition of the clusters is as follows. Cluster 1: the city of Kyiv and Kyiv region; cluster 2: Kharkiv and Odesa regions; cluster 3: four western regions - Lviv, Chernivtsi, Ivano-Frankivsk and Zakarpattia regions; cluster 4: Chernihiv, Luhansk, Donetsk, Cherkasy, Zhytomyr, Kherson, Rivne and Volyn regions; cluster 5: Ternopil, Khmelnytsky, Poltava, Zaporizhia, Dnipropetrovsk, Kirovohrad, Sumy, Mykolaiv and Vinnytsia regions.

The composition of the groups of regions by the similarity of youth migration indicators determined on the basis of Kohonen self-organizing maps 
Ward's method

Euclidean distances

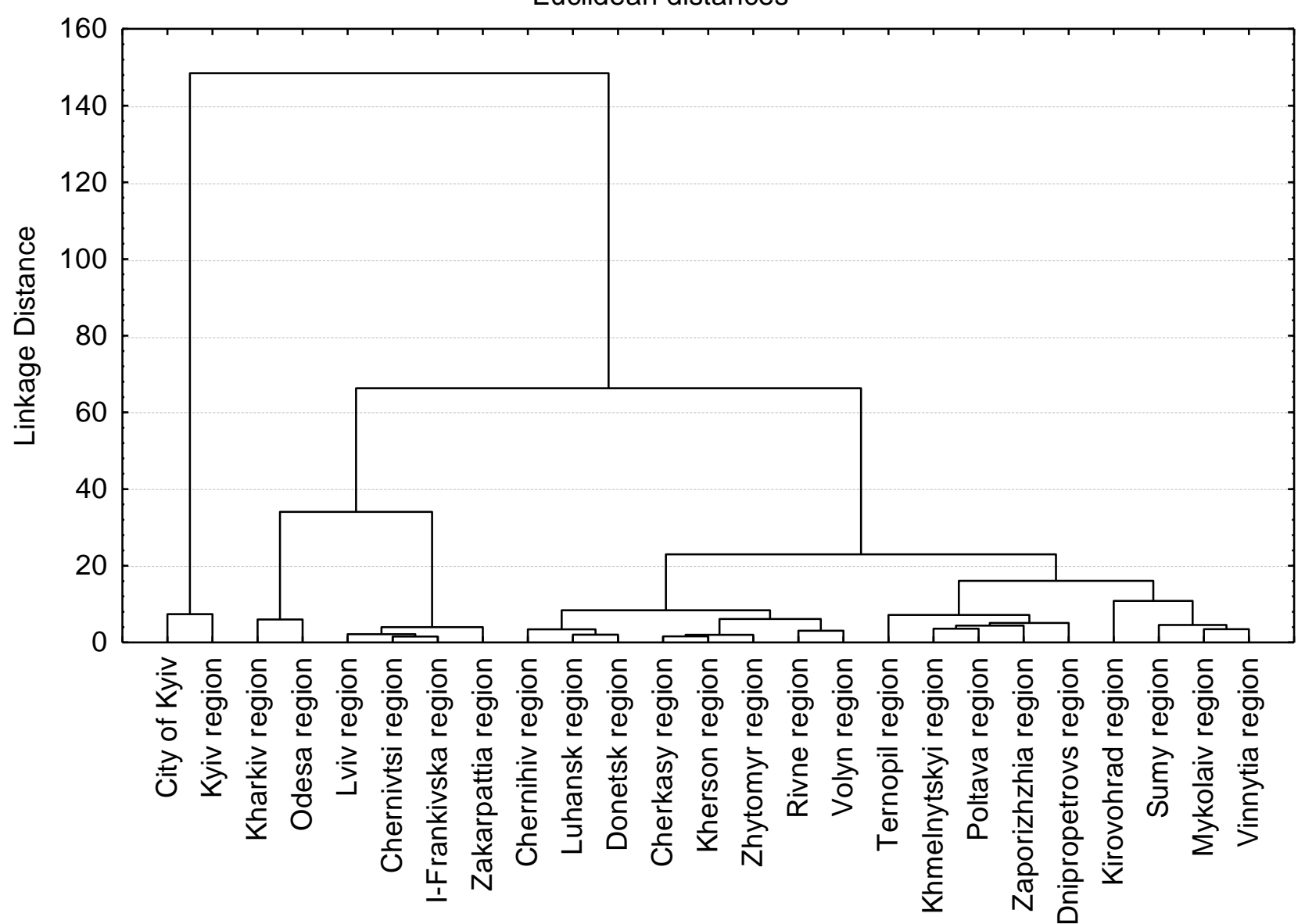

Fig. 2: Clustering of Ukraine's regions by youth migration indicators (Tree diagram)

differs somewhat. Cluster 1 (1 on the map): in addition to the city of Kyiv and Kyiv region, it also includes Kharkiv and Odesa regions, with millionplus cities as regional centers; cluster 2 (0): IvanoFrankivsk, Lviv, Khmelnytsky and Chernivtsi regions; cluster 3 (2): Zakarpattia and Ternopil regions; cluster 4 (3): Dnipropetrovsk, Zaporizhia, Poltava, Mykolaiv, Vinnytsia and Sumy regions; cluster 5 (4): Donetsk, Luhansk, Zhytomyr, Cherkasy, Kherson, Volyn, Rivne, Chernihiv and Kirovohrad regions.

The characteristics of clusters of Ukrainian regions identified on the basis of Kohonen selforganizing maps by similarity of youth migration indicators (Fig. 3, 4) are presented in Table 3.

The regional differentiation of youth migration can be explained by the location, the presence of an attractive metropolis, specialization, and level of economic development, demographic trends, labor market tensions, regional development strategy and their investment attractiveness, the presence of wellknown and prestigious higher education institutions that draw young people from other regions, the scale of economy-class housing construction for young people and families, etc.
The analysis of the youth net migration dynamics in the Ukraine's regions in 2002-2019 made it possible to conclude that there were no significant changes in the migration balance in the vast majority of regions. The only exception is Kyiv region, where the migration balance was negative in 20022006. However, it has been growing steadily since 2007.

The regional analysis of youth migration in 2002-2019 allowed to identify six models of youth migration dynamics by the indicators of inmigration, out-migration, net migration, and external migration balance (Table 4):

- monotonically decreasing

- abrupt dynamics with a tendency to decrease

- abrupt dynamics without changes (in 2019 compared to 2002)

- abrupt dynamics with a tendency to increase

- monotonically increasing

- without changes.

Based on the interpretation of clusters identified upon obtaining the results of cluster analysis (five clusters), constructed Kohonen self-organizing maps (five clusters) and models of youth migration 


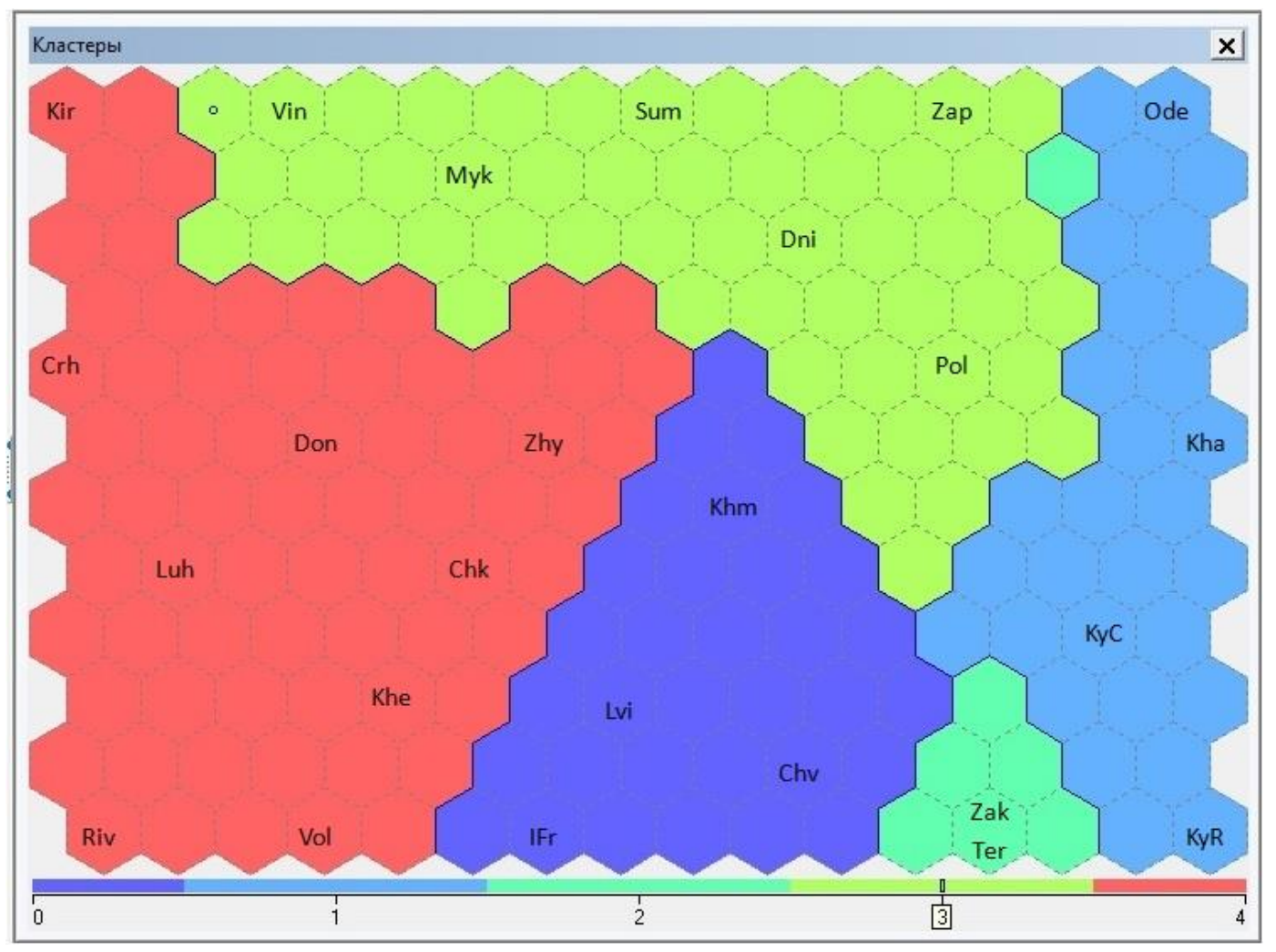

Fig. 3. Grouping of Ukraine's regions by youth migration indicators (Kohonen self-organizing map)

Table 2

Ukraine's regions clustering results (by indicators of youth migration, Kohonen self-organizing maps)

\begin{tabular}{|l|c|c|c|}
\hline \multicolumn{1}{|c|}{ Region } & Claster & Cell & $\begin{array}{c}\text { Distance to cluster } \\
\text { center }\end{array}$ \\
\hline I-Frankivsk & 0 & 182 & 0,091 \\
\hline Khmeknytskyi & 0 & 105 & 0,146 \\
\hline Lviv & 0 & 151 & 0,104 \\
\hline Chernivtsi & 0 & 170 & 0,058 \\
\hline Kyiv (region) & 1 & 191 & 0,678 \\
\hline Kyiv (city) & 1 & 142 & 0,437 \\
\hline Odesa & 1 & 15 & 0,476 \\
\hline Kharkiv & 1 & 95 & 0,559 \\
\hline Zakarpattia & 2 & 188 & 0,077 \\
\hline Ternopil & 2 & 188 & 0,0766 \\
\hline Vinnytsia & 3 & 3 & 0,181 \\
\hline Dnipropetrovsk & 3 & 42 & 0,097 \\
\hline Zaporizhzhia & 3 & 12 & 0,136 \\
\hline Mykolaiv & 3 & 21 & 0,080 \\
\hline Poltava & 3 & 76 & 0,149 \\
\hline Sumy & 3 & 8 & 0,193 \\
\hline Volyn & 4 & 179 & 0,167 \\
\hline Donetsk & 4 & 83 & 0,088 \\
\hline Zhytomyr & 4 & 86 & 0,145 \\
\hline Kirovohrad & 4 & 0 & 0,265 \\
\hline Luhansk & 4 & 113 & 0,131 \\
\hline Rivne & 4 & 176 & 0,184 \\
\hline Kherson & 4 & 117 & 0,071 \\
\hline Cherkasy & 4 & 64 & 0,070 \\
\hline Chernihiv & & & 0,090 \\
\hline
\end{tabular}




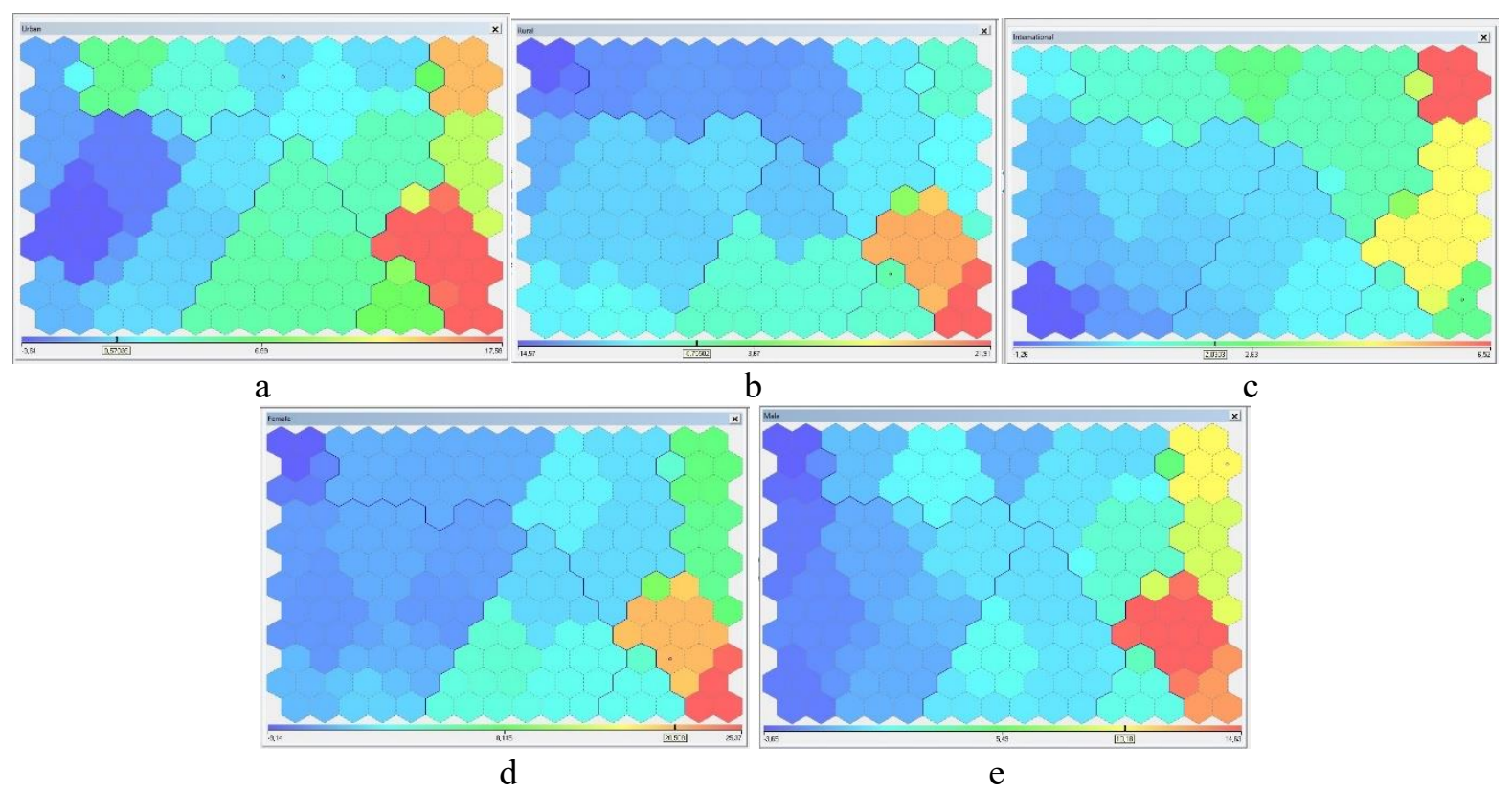

Fig. 4. The distribution correspondence of youth migrations indicators to the identified clusters of Ukrainian regions: $\mathrm{a}$ - urban, $\mathrm{b}$ - rural, $\mathrm{c}$ - external, $\mathrm{d}$ - male, $\mathrm{e}$ - female

Table 3

Characteristics of clusters by indicators of youth migration in Ukraine's regions identified on the basis of Kohonen self-organizing maps (people per thousand inhabitants)

\begin{tabular}{|c|c|c|c|c|c|}
\hline \multirow{2}{*}{ Indicators } & \multicolumn{5}{|c|}{ Clusters } \\
\hline & 1 & 2 & 3 & 4 & 5 \\
\hline $\begin{array}{l}\text { Youth net migration, } \\
\text { total }\end{array}$ & over 7,0 & $\begin{array}{c}\text { from } 1,5 \text { to } \\
-1,3\end{array}$ & $\begin{array}{c}\text { from } 0,9 \text { to } \\
-0,5\end{array}$ & $\begin{array}{c}\text { from }-0,1 \text { to } \\
-3,1\end{array}$ & $\begin{array}{c}\text { from }-2,3 \text { to } \\
-6,3\end{array}$ \\
\hline urban & over 10,0 & $4,8-3,9$ & $8,0-7,4$ & $5,4-0,6$ & $\begin{array}{c}\text { from } 0,5 \text { to } \\
-3,6\end{array}$ \\
\hline rural & $\begin{array}{c}\text { from } 21,9 \text { to } \\
-5,5\end{array}$ & $\begin{array}{c}\text { from }-2,4 \text { to } \\
-8,7\end{array}$ & $\begin{array}{c}\text { from }-2,7 \text { to } \\
-7,6\end{array}$ & $\begin{array}{c}\text { from }-6,6 \text { to } \\
-11,9\end{array}$ & $\begin{array}{c}\text { from }-4,8 \text { to } \\
-14,6\end{array}$ \\
\hline male & over 8,8 & $1,2-0,0$ & $1,6-0,4$ & $\begin{array}{l}\text { from } 1,0 \text { to } \\
-1,4\end{array}$ & $\begin{array}{c}\text { from } 0,1 \text { to } \\
-3,7\end{array}$ \\
\hline female & over 5,4 & $\begin{array}{c}\text { from } 1,8 \text { to } \\
-2,7\end{array}$ & $\begin{array}{c}\text { from } 0,3 \text { to } \\
-1,5\end{array}$ & $\begin{array}{c}\text { from }-1,1 \text { to } \\
-5,0\end{array}$ & $\begin{array}{c}\text { from }-2.9 \text { to } \\
-9,1\end{array}$ \\
\hline external & over 2,0 & $0,0-0,6$ & $0,9-2,0$ & $1,2-2,2$ & $-1,3-0,6$ \\
\hline
\end{tabular}

Source: State Statistics Service of Ukraine. http://www.ukrstat.gov.ua

dynamics for the period of 2002-2019 (six models), we developed an empirical typification of Ukrainian regions according to the migration behavior of youth.

Type 1 (Kyiv city, Kyiv, Odesa, and Kharkiv regions): regions with stable highest positive migration balance of young people in Ukraine. It includes internal and external migration in general and in urban settlements in particular, the upward trend of the youth in-migration and net migration, and external migration balance (except for the city of Kyiv, where the indicator does not changed essentially).

Type 2 (Lviv, Ivano-Frankivsk, Chernivtsi, Zakarpattia, Ternopil and Khmelnytsky regions): regions with average youth migration balance in Ukraine, positive youth net migration in urban settlements and negative in rural areas, relatively stable in-migration and net migration, consistency or reduction in the number of young people left, and increase in the external migration balance of young people. 
Models of youth migration dynamics in the regions of Ukraine, 2002-2019

\begin{tabular}{|c|c|c|c|c|}
\hline Trends in dynamics & In-migration & Out-migration & Net migration & $\begin{array}{c}\text { External migration } \\
\text { balance }\end{array}$ \\
\hline $\begin{array}{l}\text { Monotonically } \\
\text { decreasing }\end{array}$ & $\begin{array}{l}\text { Donetsk } \\
\text { Mykolaiiv } \\
\text { Rivne } \\
\text { Kherson } \\
\text { Cherkasy } \\
\text { Chernivtsi } \\
\text { Chernihiv }\end{array}$ & $\begin{array}{l}\text { Zakarpattia } \\
\text { Luhansk } \\
\text { Mykolaiiv } \\
\text { Odesa } \\
\text { Kherson } \\
\text { Khmelnytsk } \\
\text { Cherkasy } \\
\text { Chernivtsi } \\
\text { Chernihiv } \\
\text { Zaporizhzhia }\end{array}$ & $\begin{array}{l}\text { Luhansk } \\
\text { Zaporizhzhia }\end{array}$ & $\begin{array}{l}\text { Luhansk } \\
\text { Rivne }\end{array}$ \\
\hline $\begin{array}{l}\text { Abrupt dynamics with a } \\
\text { tendency to decrease }\end{array}$ & $\begin{array}{l}\text { Vinnytsia } \\
\text { Dnipropetrovsk } \\
\text { Zhytomyr } \\
\text { Luhansk } \\
\text { Khmelnytsk } \\
\text { Zaporizhzhia }\end{array}$ & $\begin{array}{l}\text { Vinnytsia Volyn } \\
\text { Dnipropetrovsk } \\
\text { Zhytomyr } \\
\text { Rivne } \\
\text { Ternopil }\end{array}$ & & \\
\hline $\begin{array}{l}\text { Abrupt dynamics } \\
\text { without changes }\end{array}$ & $\begin{array}{l}\text { Volyn } \\
\text { Kirovohrad } \\
\text { Sumy } \\
\text { Ternopil }\end{array}$ & $\begin{array}{l}\text { Kyiv (region) } \\
\text { Kirovohrad } \\
\text { Poltava } \\
\text { Sumy }\end{array}$ & $\begin{array}{l}\text { Vinnytsia } \\
\text { Poltava } \\
\text { Rivne } \\
\text { Ternopil } \\
\text { Kherson } \\
\text { Chernivtsi } \\
\text { Chernihiv } \\
\text { Kyiv (city) } \\
\text { Zaporizhzhia }\end{array}$ & $\begin{array}{l}\text { Kirovohrad } \\
\text { Poltava } \\
\text { Kherson } \\
\text { Kyiv (city) }\end{array}$ \\
\hline $\begin{array}{l}\text { Abrupt dynamics with a } \\
\text { tendency to increase }\end{array}$ & $\begin{array}{l}\text { Kyiv (region) } \\
\text { Kharkiv } \\
\text { Kyiv (city) }\end{array}$ & $\begin{array}{l}\text { Donetsk Kharkiv } \\
\text { Kyiv (city) }\end{array}$ & $\begin{array}{l}\text { Volyn } \\
\text { Zhytomyr } \\
\text { Kirovohrad } \\
\text { Odesa } \\
\text { Kharkiv }\end{array}$ & $\begin{array}{l}\text { Dnipropetrovsk } \\
\text { Odesa }\end{array}$ \\
\hline $\begin{array}{l}\text { Monotonically } \\
\text { increasing }\end{array}$ & Odesa & & $\begin{array}{l}\text { Donetsk } \\
\text { Zakarpattia } \\
\text { Ivano-Frankivsk } \\
\text { Kyiv (region) } \\
\text { Lviv } \\
\text { Sumy } \\
\text { Khmelnytsk }\end{array}$ & $\begin{array}{l}\text { Vinnytsia } \\
\text { Donetsk } \\
\text { Zakarpattia } \\
\text { Kyiv (region) } \\
\text { Lviv } \\
\text { Sumy } \\
\text { Ternopil } \\
\text { Kharkiv } \\
\text { Khmelnytsk } \\
\text { Chernivtsi } \\
\text { Zaporizhzhia }\end{array}$ \\
\hline Without changes & $\begin{array}{l}\text { Zakarpattia } \\
\text { Ivano-Frankivsk } \\
\text { Lviv } \\
\text { Poltava }\end{array}$ & $\begin{array}{l}\text { Ivano-Frankivsk } \\
\text { Lviv }\end{array}$ & $\begin{array}{l}\text { Dnipropetrovsk } \\
\text { Mykolaiv } \\
\text { Cherkasy }\end{array}$ & $\begin{array}{l}\text { Volyn } \\
\text { Zhytomyr } \\
\text { Ivano-Frankivsk } \\
\text { Mykolaiv } \\
\text { Cherkasy } \\
\text { Chernihiv }\end{array}$ \\
\hline
\end{tabular}


Type 3 (Volyn, Rivne, Vinnytsia, Zhytomyr, Chernihiv, Sumy, Cherkasy, Poltava, Kirovohrad, Kherson, Mykolaiv, Dnipropetrovsk, Zaporizhia, Donetsk, Luhansk regions): regions with a negative balance of youth migration. The indicators of their negative youth migration balance in rural areas and for women aged 15-34 threaten their demographic security. These regions are also characterized by a downward trend in the number of young people arriving and leaving.

The first type is characterized by such migration-related problems as the migration of the most educated and financially capable young people primarily to Kyiv and abroad, the lack of affordable housing for arriving young people in the metropolises, the loss of human capital in the areas with stable out-migration. Some ways to solve these problems can be a targeted information policy (especially preventive), providing counseling services for potential migrants, policies to encourage the return of young people (as a large number of migrants did not manage to gain a foothold abroad for various reasons), as well as expanding opportunities for renting social housing and affordable loans.

For the regions of the second and third types, most problems are alike with the difference that in the regions of the third group the following problems are more vivid: reduction of the reproducible workforce base, deformation of gender and age structure, conversion of temporary migration into permanent (this problem is most pronounced for the regions of the second type), reducing the level of economic development of rural areas, the emergence and expansion of depressed areas, loss of educated and skilled workforce. The ways to solve these problems can include the implementation of state and regional policies to encourage to employ young people through subsidies, giving preference to young professionals in the fields of state and/or local government, promoting legal forms of doing business (introduction of tax holidays, reduction of tax burdens), soft loans for startups, attracting young people to self-employment, ensuring equal working conditions and doing business, which requires not so much investment, but rather the implementation of appropriate reforms.

Conclusions and further research. The article analyzes the regional differentiation of youth migration flows and develops an empirical typification of the Ukrainian regions according to the special features of youth migration behavior.

The study results confirmed that economic indicators (unemployment, investment, and income) affect youth migration in Ukraine at the regional level. Still, their impact should be considered in the broader context of place-specific human capital and life-course transition [4, 22].

Regions of Ukraine differ in scale, structure, and dynamics of youth migration flows. Based on the results of cluster analysis and construction of Kohonen self-organizing maps, we identified five clusters of regions by the similarity of youth migration indicators. The study of youth migrations in 2002-2019 allowed identifying six models of youth migration dynamics. The types of regions were identified based on their combination. They can be considered as those that, to some extent, determine the migration intention of young people. The practical value of, the selected types is seen in the fact that they can become the 'guidelines' to create the migration policy in the regions.

This article is based on the results of the youth migration analysis at the regional level. However, migration aspirations strongly depend on individuals' information, perceptions, and values [26], and youth migration, especially educational, is characterized by liquidity and individualization [27]. Therefore, further research should be aimed at analyzing the individual paths and patterns of Ukrainian youth's migration behavior.

\section{Bibliography}

1. Kovacheva S. Youth Migration and Life Course Transitions: Comparing the Impact of Women's Mobility Across Generations in Bulgaria / S. Kovacheva, D. Hristozova // Sociologija. - 2019. - Vol. LXI(2). - P. 210-226. DOI: https://doi.org/10.2298/SOC1902210K

2. Bauer T. Assessment of possible migration pressure and its labor market impact following EU enlargement to Central and Eastern Europe /T. Bauer, K.F. Zimmermann. IZA Research Report No. 3. - Bonn, 1999. - 117 p.

3. Elder G.H.Jr. Attachment to place and migration prospects: A developmental perspectives / G.H.Jr. Elder, V. King, R.D. Conger // Journal of Research and Adolescence. - 1996. - Vol. 6(4). - P. 397-425.

4. Drozdzewski D. 'We're moving out': Youth Out-Migration Intentions in Coastal Non-Metropolitan New South Wales / D. Drozdzewski // Geographical Research. - 2008. - Vol. 46(2). - P. 153-161. DOI: https://doi.org/10.1111/j.1745-5871.2008.00506.x

5. Dustmann, Ch., \& Okatenko, A. (2014). Out-migration, wealth constraints, and the quality of local amenities / Ch. Dustmann, A. Okatenko // Journal of Development Economics. - 2014. - Vol. 110. - P. 52-63. DOI: https://doi.org/10.1016/j.jdeveco.2014.05.008

6. International Migration Stock. United Nations. Department of Economic and Social Affairs, 2019. Website. Peжuм docmyny: https://www.un.org/en/development/desa/population/migration/data/estimates2/estimatesgraphs.asp? $3 \mathrm{~g} 3$

7. Velychko K. Yu. The Phenomenon of Student Migration in Ukraine / K.Yu. Velychko, M.O. Yaremenko M. O. Бiзнeсінформ. - 2020. - №5. - C. 62-70. DOI: https://doi.org/10.32983/2222-4459-2020-5-62-70 
8. Мельничук Д.П. Міграційні наміри студентської молоді та їх вплив на мотиваційну складову людського капіталу України / Д.П. Мельничук // Демографія та сочіальна економіка. - 2009. - № 1. - C. $116-124$.

9. Фесенко А.М. Освітньо-трудова міграція освіченої молоді як тренд сучасної доби: соціологічний аналіз / А.М. Фесенко, В.О. Чорна, С.М.Осіпова // Габітус. - 2018. - Вип. 6. - С. 130-136.

10. Павліха Н.В.. Становлення освітньої міграџї̈ в умовах глобалізаџії / Н.В. Павліха, Н.А. Степанюк // Глобальні та національні проблеми економіки. - 2017. - Вип. 16. - C. 219-223.

11. Grzymala-Kazłowska A. From drifting to anchoring. Capturing the experience of Ukrainan migrants in Poland / A. Grzymala-Kazłowska, A. Brzozowska // Central and Eastern European Migration Review.- 2017. - Vol.6(2). - P. 103-122. DOI: https://doi.org/10.17467/ceemr.2017.04

12. Лібанова Е. М. Зовнішні трудові мігращії украӥниів: масштаби, причини, наслідки / Е. М. Лбанова // Демографія та сочіальна економіка. - 2018. - № 2(33). - C. 11-26. DOI: https://doi.org/10.15407/dse2018.02.11

13. Щерба Г.І. Трудова міграція молоді та ї̈ наслідки для дітей в украӥнському суспільстві/ Г.І. Щерба // Український соиіум. - 2011. - № 3(38). - C. 161-168. DOI: https://doi.org/10.15407/socium2011.03.161

14. Niemets L., Lohvynova M., Sehida K., Husieva N., Kravchenko K. Modern challenges of external labor migration in Ukraine. // Vision 2025: Education Excellence and Management of Innovations through Sustainable Economic Competitive Advantage Growth [Ed. by Kh.S. Soliman]. - Madrid, IBIMA, 2019. - P. 516-528.

15. Sehida K., Husieva N., Niemets L., Suptelo O., Kobylin P., Kliuchko L. Migration Challenges of the 21st Century: The Experience of Ukraine // Vision 2020: Sustainable Economic Development and Application of Innovation Management from Regional Expansion to Global Growth [Ed. by Kh.S. Soliman]. - Seville, IBIMA, 2018. - P. $328-337$.

16. Мезенцев К. Економічні фактори регіональної диферениіації безробіття та міграційних намірів молоді в Україні / К. Мезенцев, Н. Провотар, В. Паренюк // Вісник Київького національного університету імені Таpaca Шевченка. Географія. - 2020. - № 1-2(76-77). - C. 16-23. DOI: https://doi.org/10.17721/17282721.2020.76-77.2

17. Punch S. Moving for a better life: To stay or to go / S. Punch // Key issues in childhood and youth studies [Ed. by D. Kassem, L. Murphy, E. Taylor]. - New York: Routledge, 2010. - P. 202-216.

18. Pollard K. Selective migration of rural high school seniors in the 1980s / K. Pollard, W.P. O'Hare, R. Berg. Washington DC: Population Reference Bureau, 1990.

19. Easthope H. Turbulent lives: Exploring the cultural meaning of regional youth migration / H. Easthope, M. Gabriel M. // Geographical Research. - 2008. - Vol. 46(2). - P. 172-182. DOI: https://doi.org/10.1111/j.1745$\underline{5871.2008 .00508 . x}$

20. Malamassam M.A. Youth Migration in Indonesia: Decision to Move and to Choose Destination Areas / M.A. Malamassam // Indonesian Journal of Geography. - 2016. - Vol. 48(1). - P. 61-71. DOI: https://doi.org/10.22146/ijg. 12469

21. Heckert J. New perspective on youth migration: Motives and family investment patterns/ J. Heckert // Demographic Research. - 2015. Vol.33. - P. 765-800. DOI: https://doi.org/10.4054/DemRes.2015.33.27

22. Lulle A. Introduction to the Special Issue: European youth migration: human capital outcomes, skills and competences / A. Lulle, H. Janta, H. Emilsson // Journal of Ethnic and Migration Studies. - 2021. - Vol. 47(8). - P. 17251739. DOI: https://doi.org/10.1080/1369183X.2019.1679407

23. Nugin R. "I think that they should go. Let them see something". The context of rural youth's out-migration in postsocialist Estonia / R. Nugin // Journal of Rural Studies. - 2014. - Vol. 34. - P. 51-64. DOI: https://doi.org/10.1016/j.jrurstud.2014.01.003

24. McKenzie D.J. A profile of the world's young developing country international migrants / D.J.McKenzie // Population and Development Review. - 2008. - Vol. 34(1). - P. 115-135. DOI: https://doi.org/10.1111/j.17284457.2008.00208.x

25. Roth B.J. Creating reasons to stay? Unaccompanied youth migration, communitybased programs, and the power of "push" factors in El Salvador / B.J. Roth, C.S. Hartnett // Children and Youth Services Review. - 2018. - Vol. 92. P. 48-55. DOI: https://doi.org/10.1016/j.childyouth.2018.01.026

26. Van Mol Ch. Migration aspirations and migration cultures: A case study of Ukrainian migration towards the European Union / Ch. Van Mol, E. Snel, K. Hemmerechts, Ch. Timmerman // Population, Space and Place. - 2018. Vol. 24(5). - P. e2131. DOI: https://doi.org/10.1002/psp.2131

27. Engbersen G. Migration transitions in an era of liquid migration / G. Engbersen // European Immigrations. Trends, Structures and Policy Implications [Ed. by M. Okólski] - Amsterdam University Press, 2012. - P. 91-106. DOI: https://doi.org/10.1515/9789048517275-005

28. Hörschelmann K. (2009). Routes through the city: youth identities and spatial practices in Leipzig / K. Hörschelmann // Public spheres after socialism [A. Harutyunyan, K. Hörschelmann, M. Miles]. - Bristol: Intellect Ltd., 2009. - P. 92-109.

29. Burrell K. Opportunity and uncertainty: young people's narratives of 'double transition' in post-socialist Poland / K. Burrell // Area. - 2011. - Vol. 43(4). - P. 413-419. DOI: https://doi.org/10.1111/j.1475-4762.2011.01024.x

30. Mezentsev K. (2014). Ukraine: stable outflow and changing nature / K. Mezentsev, G. Pidgrushnyi. // Discovering migration between Visegrad countries and Eastern Partners [Ed. by Á. Eröss \& D. Karacsonyi]. - Budapest: HAS RCAES Geographical Institute, 2014. - P. 191-211.

31. Elizbarashvili N., Niemets L., Meladze G., Sehida K., Lohvynova M., Meladze M., Sidamonidze D. (2020). Forced migrations of Georgia and Ukraine: reasons for the emergence, process features, implications for countries 
// Visnyk of V.N. Karazin Kharkiv National University, series "Geology. Geography. Ecology". - 2019. - Vol. 52. P. 139-155. DOI: https://doi.org/10.26565/2410-7360-2020-52-11

32. Мезенцев К.В. Міграційна поведінка студентської молоді: илях до кар'єри за кордоном чи ситуативна можливість самореалізащії? / К.В. Мезенцев, Н.І. Мезенцева // Регіон-2018: пошук стратегї оптимального розвитку [За ред. Л.М. Нємецьь]. - Харків: Харківський національний університет імені В.Н.Каразіна, 2018. C. 33-37.

33. Мезенцев К.В. Суспільно-географічне прогнозування регіонального розвитку / К.В. Мезенцев. - Київ: ВПЦ «Київський університет», 2005. - 253 c.

Submitted April 24, 2021

Accepted May 08, 2021

Authors Contribution: Authors contributed to this work equally.

UDC 911.3:314.7

Victor Parenyuk,

PhD student, Department of Economic and Social Geography,

Taras Shevchenko National University of Kyiv, 64/13 Volodymyrska St., Kyiv, 01601, Ukraine, e-mail: parenvic@i.ua, https://orcid.org/0000-0001-7098-6977;

Nataliia Provotar,

$\mathrm{PhD}$ (Geography), Associate Professor of Department of Economic and Social Geography,

Taras Shevchenko National University of Kyiv, e-mail: provotarnat@ukr.net, https://orcid.org/0000-0003-2211-6509;

\section{Kostyantyn Mezentsev,}

DSc (Geography), Head of Department of Economic and Social Geography,

Taras Shevchenko National University of Kyiv, e-mail: mezentsev@knu.ua, https://orcid.org/0000-0003-1974-7860

\section{YOUTH MIGRATION IN UKRAINE: REGIONAL DESTINY}

Purpose. This study aims to analyze the regional differentiation of youth migration flows and typify the regions of Ukraine according to the characteristics of the migratory behavior of the youth. Accordingly, the research questions are as follows: 1) what is the relationship between economic indicators (income, unemployment, investment) and youth migration at the regional level? 2) how do the regions of Ukraine differ in the scale, structure, and dynamics of youth migration flows? 3) what types of regions can be identified, and can they be considered to determine the young people's intention to migrate?

Research methods. Pearson's correlation coefficients were calculated to assess the relationship between youth migration and economic indicators at the regional level. To prevent skewed indicators distribution, the city of Kyiv was excluded from the analysis. In order to study the regional differentiation of youth migration, we used cluster analysis and constructed Kohonens self-organizing maps. Based on the analysis of spatial and temporal (from 2002 to 2019) trends, we also developed an empirical typification of the regions according to the migration behavior of young people.

Main findings. The analysis of spatial differences in youth migration in urban and rural areas shows the diversity and complicated multidirectionality of migration flows. Youth migration has been found to be linked to unemployment and investment attractiveness at the regional level. The assumption that the migration of young people from rural areas is influenced not only by economic factors but also by the lack of prospects for tertiary education, jobs, and the 'culture of migration' has been confirmed. The analysis of the relationship between income and out-migration scale shows some signs of a inverse U-shape curve. In general, the results of the study confirmed that at the regional level, economic indicators (unemployment, investment, and income) affect youth migration in Ukraine, but their impact needs to be studied in the broader context of place-specific human capital and life-course transition. Based on the results of cluster analysis and construction of Kohonen self-organizing maps, five clusters of Ukraine's regions by the similarity of youth migration were identified. The analysis of youth migrations in 2002-2019 allowed to identify six models of their dynamics (monotonically decreasing, abrupt dynamics with a tendency to decrease, abrupt dynamics without changes, abrupt dynamics with a tendency to increase, monotonically increasing, without changes). According to the combination of selected clusters of regions and models of youth migration dynamics, we empirically typified Ukraine's regions into three groups that can be considered those that, to some extent, determine 
the young people's intention to migrate. However, further research should be aimed at analyzing the individualization of migration behavior and liquid migration of Ukrainian youth.

Scientific novelty and practical value. The main novelty of the study is its focus on the spatial dimension of youth migration in Ukraine, particularly identifying the features of regional differentiation of migration flows, factors, trends and regional problems associated with youth migration. The practical value of the obtained results lies in the possibility for certain types of regions to become 'guidelines' for the migration policy in the regions of Ukraine.

Keywords: youth, migrations, region, migration factors, typification, Ukraine

\section{References}

1. Kovacheva, S., \& Hristozova, D. (2019), Youth Migration and Life Course Transitions: Comparing the Impact of Women's Mobility Across Generations in Bulgaria. Sociologija, LXI(2), 210-226. DOI: https://doi.org/10.2298/SOC1902210K

2. Bauer, T., \& Zimmermann, K.F. (1999). Assessment of possible migration pressure and its labor market impact following EU enlargement to Central and Eastern Europe. IZA Research Report No. 3. Bonn, 117 p.

3. Elder, G.H.Jr., King, V., \& Conger, R.D. (1996). Attachment to place and migration prospects: A developmental perspectives. Journal of Research and Adolescence, 6(4), 397-425.

4. Drozdzewski, D.(2008). 'We're moving out': Youth Out-Migration Intentions in Coastal Non-Metropolitan New South Wales. Geographical Research, 46(2), 153-161. DOI: https://doi.org/10.1111/j.1745-5871.2008.00506.x

5. Dustmann, Ch., \& Okatenko, A. (2014). Out-migration, wealth constraints, and the quality of local amenities. Journal of Development Economics, 110, 52-63. DOI: https://doi.org/10.1016/j.jdeveco.2014.05.008

6. International Migration Stock (2019). United Nations. Department of Economic and Social Affairs.Available at: https://www.un.org/en/development/desa/population/migration/data/ estimates2/estimatesgraphs.asp?3g3

7. Velychko K. Yu., Yaremenko M. O. (2020). The Phenomenon of Student Migration in Ukraine, Biznesinform, 5, 6270. DOI: https://doi.org/10.32983/2222-4459-2020-5-62-70

8. Mihratsiini namiry studentskoii molodi ta ikh vplyv na motyvatsiinu skladovu liudskoho kapitalu Ukraiiny [Migration intentions of student youth and their impact on the motivational component of human capital in Ukraine]. Demography and Social Economy, 1(11), 116-124. [In Ukrainian]

9. Fesenko, A.M., Chorna, V.O., \& Osipova, Y.M. (2018). Osvitnoi-trudova mihratsiia osvichenoii molodi iak trend suchasnoii doby: sociolohichyi analiz [Educational and labour migration of educated youth as the trend of modernity: a sociological analysis]. Habitus, 6, 130-136. [In Ukrainian]

10. Pavlikha, N.V., Stepaniuk, N.A. (2018). Stanovleniia osvitnoii mihratsii v umovakh hlobaliatsii [Educational migration under the conditions of globalization]. Global and national economic problems, 16, 219-223. [In Ukrainian]

11. Grzymala-Kazłowska, A., \& Brzozowska, A. (2017). From drifting to anchoring. Capturing the experience of Ukrainan migrants in Poland. Central and Eastern European Migration Review, 6(2), 103-122. DOI: https://doi.org/10.17467/ceemr.2017.04

12. Libanova, E.M. (2018). Zovnishni trudovi mihratsii ukraintsiv: masshtaby,prychyny, naslidky [External labor migration of Ukrainians: scale, causes, consequences]. Demography and Social Economy, 2(33), 11-26. [In Ukrainian] DOI: https://doi.org/10.15407/dse2018.02.11

13. Shcherba, G. I. (2011). Trudova mihratsiia molodi ta ii naslidky dlia ditei v ukarinskomu suspilstvi [Labour migration of youth and its consequences for children in Ukrainian society]. Ukrainian Society, 3(38), 161-168. [In Ukrainian] DOI: https://doi.org/10.15407/socium2011.03.161

14. Niemets, L., Lohvynova, M., Sehida, K., Husieva, N., \& Kravchenko, K. (2019). Modern challenges of external labor migration in Ukraine. In: Soliman, Kh.S. (ed.), Vision 2025: Education Excellence and Management of Innovations through Sustainable Economic Competitive Advantage (516-528). Madrid, IBIMA.

15. Sehida, K., Husieva, N., Niemets, L., Suptelo, O., Kobylin, P., \& Kliuchko, L. (2018). Migration challenges of the 21 st century: The experience of Ukraine. In: Soliman, Kh.S. (ed.), Vision 2020: Sustainable Economic Development and Application of Innovation Management from Regional Expansion to Global Growth (pp. 328-337). Seville, IBIMA.

16. Mezentsev, K., Provotar, N., \& Pareniuk, V. (2020). Ekonomichni faktory rehionalnoi dyferentsiatsii bezrobittia ta mihratsiinykh namiriv molodi $v$ Ukraini [Economic factors of regional differentiation of young people's unemployment and migration]. Bulletin of Taras Shevchenko National University of Kyiv. Geography, 1-2(76-77), 16-23. [In Ukrainian] DOI: https://doi.org/10.17721/1728-2721.2020.76-77.2

17. Punch, S. (2010). Moving for a better life: To stay or to go. In: D. Kassem, L. Murphy, \& E. Taylor (eds.), Key issues in childhood and youth studies (pp. 202-216). New York: Routledge.

18. Pollard, K., O'Hare, W.P., \& Berg, R. (1990). Selective migration of rural high school seniors in the 1980s. Washington DC: Population Reference Bureau.

19. Easthope, H., \& Gabriel, M. (2008). Turbulent lives: Exploring the cultural meaning of regional youth migration. Geographical Research, 46(2), 172-182. DOI: https://doi.org/10.1111/j.1745-5871.2008.00508.x

20. Malamassam, M.A. (2016). Youth Migration in Indonesia: Decision to Move and to Choose Destination Areas, Indonesian Journal of Geography, 48(1), 61-71. DOI: https://doi.org/10.22146/ijg.12469 
21. Heckert, J. (2015). New perspective on youth migration: Motives and family investment patterns. Demographic Research, 33, 765-800. DOI: https://doi.org/10.4054/DemRes.2015.33.27

22. Lulle, A., Janta, H., \& Emilsson, H. (2021). Introduction to the Special Issue: European youth migration: human capital outcomes, skills and competences. Journal of Ethnic and Migration Studies, 47(8), 1725-1739. DOI: https://doi.org/10.1080/1369183X.2019.1679407

23. Nugin, R. (2014). "I think that they should go. Let them see something”. The context of rural youth's out-migration in post-socialist Estonia. Journal of Rural Studies, 34, 51-64. DOI: https://doi.org/10.1016/j.jrurstud.2014.01.003

24. McKenzie, D.J. (2008). A profile of the world's young developing country international migrants. Population and Development Review, 34(1), 115-135. DOI: https://doi.org/10.1111/j.1728-4457.2008.00208.x

25. Roth, B.J., \& Hartnett, C.S. (2018). Creating reasons to stay? Unaccompanied youth migration, communitybased programs, and the power of "push" factors in El Salvador. Children and Youth Services Review, 92, 48-55. DOI: https://doi.org/10.1016/j.childyouth.2018.01.026

26. Van Mol, Ch., Snel, E., Hemmerechts, K., \& Timmerman, Ch. (2018). Migration aspirations and migration cultures: A case study of Ukrainian migration towards the European Union. Population, Space and Place, 24(5), e2131. DOI: https://doi.org/10.1002/psp.2131

27. Engbersen, G. (2012), Migration transitions in an era of liquid migration. In: Okólski, M. (ed.), European Immigrations. Trends, Structures and Policy Implications (91-106). Amsterdam University Press. DOI: https://doi.org/10.1515/9789048517275-005

28. Hörschelmann, K. (2009). Routes through the city: youth identities and spatial practices in Leipzig. In: Harutyunyan A., Hörschelmann K, \& Miles, M (eds.) Public spheres after socialism (pp. 92-109), Bristol: Intellect Ltd.

29. Burrell, K. (2011). Opportunity and uncertainty: young people's narratives of 'double transition' in post-socialist Poland. Area, 43(4), 413-419. DOI: https://doi.org/10.1111/j.1475-4762.2011.01024.x

30. Mezentsev, K., Pidgrushnyi, G. (2014). Ukraine: stable outflow and changing nature. In: Á. Eröss \& D. Karacsonyi (eds.), Discovering migration between Visegrad countries and Eastern Partners (pp. 191-211). Budapest: HAS RCAES Geographical Institute.

31. Elizbarashvili, N., Niemets, L., Meladze, G., Sehida, K., Lohvynova, M., Meladze, M., \& Sidamonidze, D. (2020). Forced migrations of Georgia and Ukraine: reasons for the emergence, process features, implications for countries. Visnyk of V.N. Karazin Kharkiv National University, series "Geology. Geography. Ecology", 52, $139-155$. DOI: https://doi.org/10.26565/2410-7360-2020-52-11

32. Mezentsev, K., \& Mezentseva, N. Mihratsiina povedinka studentskoi molodi:shliakh do kariery za kordonom chy sytuatyvna mozhkyvist samorealizatsii? [Migratory behavior of student youth: a path to a career abroad or a situational opportunity for self-realization?] In: Niemets, L. (ed.), Rehion-2018: poshuk stratehii optymalnoho rozvytku [Region-2018: Search for optimal development strategy] (33-37). Kharkiv, V.N. Karazin Kharkiv National University. [In Ukrainian]

33. Mezentsev, K. (2005). Suspilno-heohrafichne prohnozuvaniia rehionalnoho rozvytku [Socio-geographical forecasting of regional development]. Kyiv, Kyiv University, 253. [In Ukrainian] 